5. Kulygina V.N., M.Al' Mokhamed, Kozlova L.L. Results of the study of the prevalence and structure of periodontal diseases in young people. Ukrai'ns'kyj stomatologichnyj al'manah. 2013;5:29-31.

6. Tkachenko A.G., Lukashevich M.V., Yarmolenko K.P. Assessment of periodontal tissue morbidity in young people. Materials of the 1st international Slavic scientific and practical conference of young dental scientists. Odessa; 2002:29-30.

7. Jenkins W.M., Papapanou P.N. Epidemiology of periodontal disease in children and addescents. Peroidontal. 2000;26:16-32.

8. Papapanou P.N. Epidemiology of periodontal disease. an update. J.int.acad. periodontal. 1999;1:110-116.

9. Wolf J., Peltola J.S., Seedre T. [et al]. Dental health in 14 to 17 years old. Estonian school-children in Tartu and Tallin. Aeta Odontologia Scandinsvica. 1996;54(4):242-246.

10. Muntyan L.M., Yur A.M. The incidence of, Prevalence of secondary partial adentia and jaw deformities in persons of young age. Ukrai'ns'kyj stomatologichnyj al'manah. 2010;5:25-26.

11. Labunec' O.V. Klinichne obg'runtuvannja rann'ogo ortopedychnogo likuvannja malyh vkljuchenyh defektiv zubnyh rjadiv u molodomu vici [Clinical justification of early orthopedic treatment of small included defects of dentition at a young age:] Abstract of a candidate's thesis of medical sciences. Odesa; 2015:20

12. Ozhogan Z.R., Vdovenko L.P. Features of the clinical picture of dental defects in young people. Dental'ni patologii'. 2006;3-6 (28-31):19-21.

13. Stomatologicheskie obsledovaniya: Osnovnye metody [Dental examinations: Basic methods]. Zheneva, VOZ; 1989:62.

14. Epidemiologiya etiologiya i profilaktika bolezney parodonta [Epidemiology etiology and prevention of periodontal diseases]. Doklad nauchnoy gruppy VOZ. Zheneva;1980:66.

Надійшла 29.13.20

УДК 616-08.846+616.314-089.28/.29.004.64

DOI https://doi.org/10.35220/2523-420X/2020.1.8

С.А. Шнайдер, д. мед. н., Е. И. Семенов, к. мед. н., О. Н. Сенников, к. мед. н.

Государственное учреждение «Институт стоматологии и челюстно-лицевой хирургии Национальной академии медицинских наук Украины»

\title{
МУЛЬТИМОДАЛЬНЫЙ ПОДХОД ПРИ СОЗДАНИИ ОПОРЫ ПОД НЕСЪЕМНУЮ ОРТОПЕДИЧЕСКУЮ КОНСТРУКЦИЮ С ПОМОЩЬЮ ДЕНТАЛЬНЫХ ИМПЛАНТАТОВ
}

Сочетание различных видов дентальных имплантатов, для создания опор под несъемные ортопедические конструкции является эффективной методикой по восстановлению функции жевания ничем не уступающей, той когда в качестве опор несъемных мостовидных протезов использовались только двухэтапные винтовые имплантаты

Ключевые слова: имплантат, ортопедическая конструкция, мультимодальный подход.

\section{С.А. Шнайдер, С. І. Семенов, О. М. Сенніков}

Державна установа «Інститут стоматології та щелепно-лицевої хірургії Національної академії медичних наук України»

\section{МУЛЬТИМОДАЛЬНИЙ ПІДХІД ПРИ СТВОРЕННІ ОПОРИ ПІД НЕЗНІМНУ ОРТОПЕДИЧНУ КОНСТРУКЦІЮ ЗА ДОПОМОГОЮ ДЕНТАЛЬНИХ ІМПЛАНТАТІВ}

Поєднання різних видів дентальних імплантатів, для створення опори під незнімні ортопедичні конструкиії є ефективною методикою по відновленню функиії жування нічим не поступається, тій в якості якій опори незнімних мостоподібних протезів використовувалися тільки двоетапні гвинтові імплантати

Ключові слова: імплантат, ортопедична конструкиія, мультимодальний підхід. 


\title{
S. A. Shnayder, E. I. Semenov, O. N. Sennikov, *A. F. Dzygal \\ State Establishment «The Institute of Stomatology and Maxillo-Facial Surgery National Academy of Medical Science of Ukraine» \\ *Odessa National Medical University \\ MULTI-MODAL APPROACH FOR CREATING A SUPPORT FOR A FIXED ORTHOPEDIC STRUCTURE USING DENTAL IMPLANTS'
}

\begin{abstract}
The combination of the different types of dental implants for the support for the fixed orthopedic constructions is the effective method of the restoration of the mastication function, being not worse than the one, at which two-stage screw implants are used as the supports for the fixed dental bridges.
\end{abstract}

Key words: implant, orthopedic construction, multimodal approach.

В последнее время двухэтапные винтовые имплантаты вытесняют (на наш взгляд необоснованно) другие виды имплантатов (субпериостальные, пластиночные, винтовые установленные по одноэтапной методике) при создании опоры под несъемную мостовидную ортопедическую конструкцию $[1,3,4,11]$.

Надежная остеоинтеграция (при оптимальном подборе длинны и диаметра внутрикостной части имплантата), возможность при помощи абатманов с различным углом наклона создать параллельность между элементами опор несъемного мостовидного протеза с максимальным сохранением ее высоты и объема, обеспечивающая его надежную фиксацию, является положительным аспектом при использовании этой методики.

Наряду с этим применение этих имплантатов сопряжено с необходимостью наличия большого массива костной ткани, а ее часто недостаточно, в связи с неблагоприятными анатомическими особенностями строения челюстей (низкопосаженное дно гайморовой полости, сильная атрофия альвеолярного гребня челюстей, как по высоте, так и по ширине, близко расположенный к надкостнице альвеолярного отростка нижней челюсти канал нижнечелюстного нерва и др.)

В последнее время появилось большое количество остеопластических материалов с разным механизмом остеообразования, что делает методику направленной регенерации костной ткани очень эффективной, и дает возможность избежать большинства проблем, связанных с неблагоприятными анатомическими особенностями строения челюстей (как врожденными, так и приобретенными) [9].

Однако, применение этой методики, сопряжено с необходимостью нескольких оперативных вмешательств, что отдаляет сроки окончания лечения, а также не всегда возможно по общемедицинским показаниям. Кроме этого, в последнее время в связи с общеэкономическими проблемами многие пациенты отказываются от этой затратной методики, и просят найти альтернативные пути решения своей проблемы $[2,5-8$, $10]$.

Таким образом, на основании вышеперечисленных причин целью нашей работы является, на основании 20 летнего клинического опыта изучить возможность применения различных видов имплантатов (субпериостальных, пластиночных, винтовых установленных по одноэтапной методике) в сочетании как между собой, так и в комплексе с двухэтапными винтовыми цилиндрическими имплантатами при создании опоры под несъемную ортопедическую конструкцию при дефектах зубного ряда различной протяженности.

Материалы и методы. Анализ результатов реабилитации пациентов с вторичной адентией несъемными мостовидными протезами опирающиеся на различные виды имплантатов в разном сочетании и где в качестве опоры выступали двухэтапные винтовые имплантаты (группа сравнения) проводились по обращаемости. В ходе проведения работы нами осматривались, только пациенты, которые пользовались изготовленными нами ортопедическими конструкциями с опорой на дентальные имплантаты не менее 2-х лет, и в течении этого срока не предъявляли никаких жалоб. Это по нашему мнению позволяет, при анализе результатов, исключить лиц, у которых осложнения возникли вследствие нарушения протокола установки дентальных имплантатов.

Всего было обследовано 72 пациента, у которых опорой несъемных мостовидных протезов служили двухэтапные винтовые цилиндрические имплантаты (I группа, группа сравнения) (рис. 1).

II группу составили 25 пациентов у которых двухэтапные винтовые имплантаты установленные во фронтальном отделе челюсти, сочетались 
с пластиночными имплантатами в дистальных отделах челюсти (рис. 2).

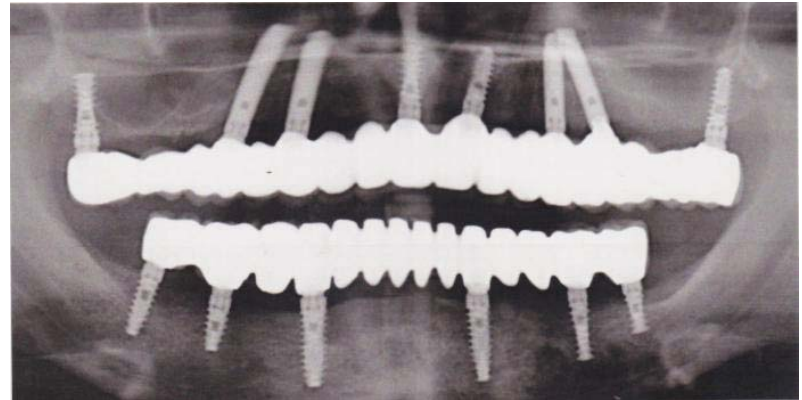

Рис. 1. Опорой несъемных мостовидных протезов служили двухэтапные винтовые цилиндрические имплантаты.

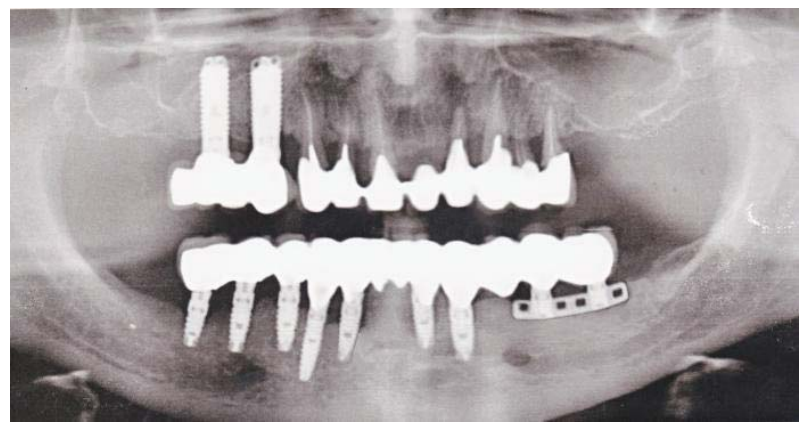

Рис 2. Двухэтапные винтовые имплантаты установленные во фронтальном отделе челюсти, сочетались с пластиночными имплантатами в дистальных отделах челюсти.

III группу составили 21 пациент у которых пластиночные имплантаты установленные в дистальных отделах челюстей, сочетались с винтовыми имплантатами, установленные по одноэтапной методике во фронтальном отделе челюсти (рис. 3).

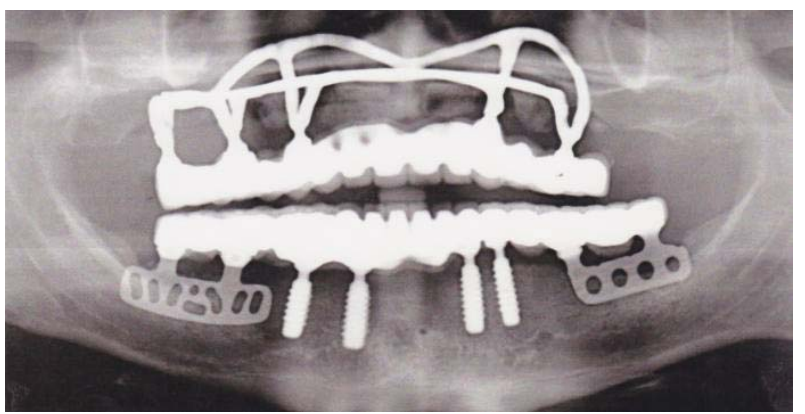

Рис. 3. Пластиночные имплантаты установленные в дистальных отделах челюстей, сочетались с винтовыми имплантатами, установленные по одноэтапной методике во фронтальном отделе челюсти.

IV группу составило 16 пациентов у которых двухэтапные винтовые имплантаты в сочетании с винтовыми имплантатами установленные по одноэтапной методике служили опорами несъемных мостовидных протезов (рис. 4).

$\mathrm{V}$ гурппа 11 человек, у которых субпериостальные имплантаты сочетались с двухэтапны- ми винтовыми в качестве опоры несъемных мостовидных протезов (рис. 5).

VI группу составили 9 пациентов у которых субпериостальные имплантаты сочетались с пластиночными при создании опоры под несъемную ортопедическую конструкцию (рис. 6).

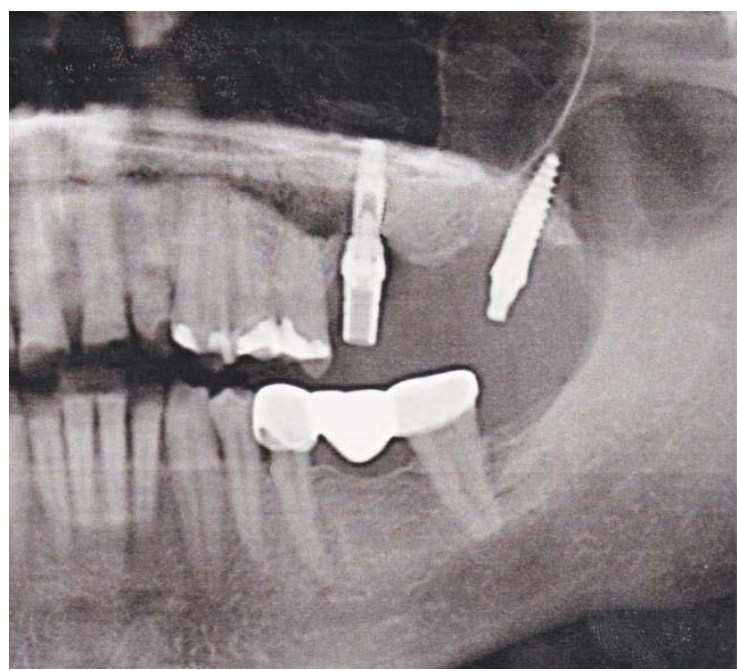

Рис. 4. Двухэтапные винтовые имплантаты в сочетании с винтовыми имплантатами установленные по одноэтапной методике служили опорами несъемных мостовидных протезов.

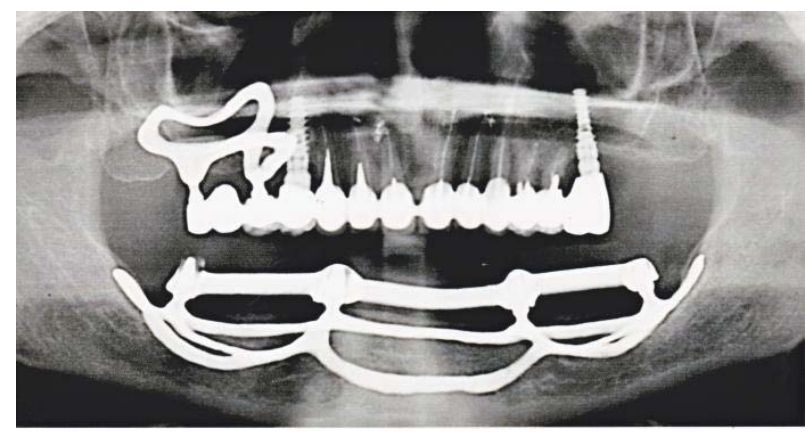

Рис. 5. Субпериостальные имплантаты сочетались с двухэтапными винтовыми в качестве опоры несъемных мостовидных протезов.

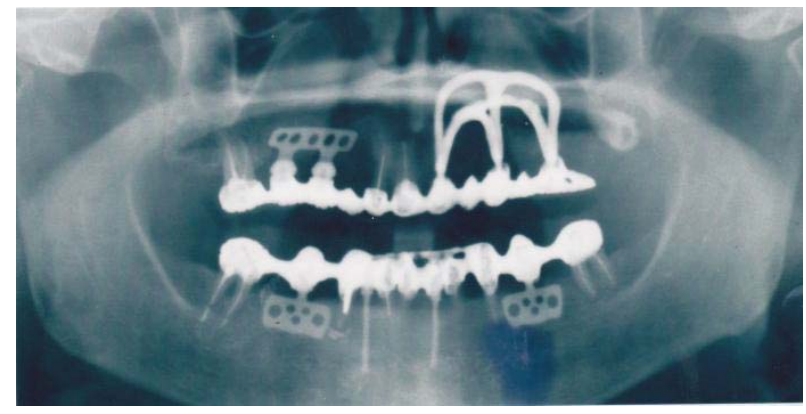

Рис. 6. Субпериостальные имплантаты сочетались с пластиночными при создании опоры под несъемную ортопедическую конструкцию.

Надо отметить, что у всех пациентов (V и VI групп) субпериостальный имплантат был установлен ранее и служил дистальной опорой мос- 
товидного протеза при одностороннем или двухстороннем дистально-неограниченном дефекте зубного ряда, а двухэтапные винтовые и пластиночные имплантаты были установлены позже по факту потери зубов на челюсти в силу различных причин.

Анализ результатов и их обсуждение. Результаты обследований заносились в таблицу.

Таблица

Анализ результатов и их обсуждение

\begin{tabular}{|l|c|c|c|c|c|c|}
\hline \multicolumn{1}{|c|}{ № группы } & I & II & III & IV & V & VI \\
\hline К-во пациентов & 72 & 25 & 21 & 16 & 11 & 9 \\
\hline Осложнения, связанные с нарушениями остеоинте- & & & & & & \\
грации при снятии ортопедической конструкции (к- & 6 & 2 & 2 & 1 & 1 \\
во пациентов) & 7 & 8 & 8 & 7 & 7 & 7 \\
& 7 & & & & \\
Сроки службы несъемной ортопедической конст- & 8 & 9 & 10 & & \\
рукции до снятия & 8 & & & & \\
& 11 & & & & \\
\hline \% осложнений & 8,5 & 8 & 9,5 & 6,3 & 9,1 & 11,1 \\
\hline
\end{tabular}

Количество пациентов в І-й группе, которым необходимо было снимать мостовидный протез в связи с нарушением остеоинтеграции в области одного или нескольких имплантатов составило 6 человек, или 8,3 \% от общего количества пациентов в группе (минимальный срок службы ортопедической конструкции до снятия составил 7 лет, максимальный 12 лет).

У пациентов II группы мостовидный протез необходимо было удалять у 2-х пациентов, что составило $8 \%$ от общего количества пациентов в группе. Срок службы протезов составил 8 и 9 лет. В 3 группе ортопедическую конструкцию необходимо было снимать у двух пациентов, что составило 9,5 \% от общего количества пациентов в группе (срок службы ее составил 8 и 10 лет).

B IV группе нуждался в снятии 1 мостовидный протез или 6,3 \% от общего количества пациентов в группе (срок службы ортопедической конструкции на момент снятия составил 7 лет).

У пациентов V группы процент осложнений составил 9\% от общего количества в группе. У одного пациента мостовидный протез нуждался в снятии (срок службы его с момента установки двухэтапных цилиндрических имплантатов составило 7 лет).

В VI группе нуждался в снятии один протез спустя 6 лет после установки пластиночных имплантатов, что составило $11,1 \%$ от общего количества пациентов в группе.

Процент осложнений у лиц, у которых опорой несъемного мостовидного протеза служили двухэтапные винтовые цилиндрические имплантаты (первая групп) составил 8,3 \% от общего количества пациентов в этой группе, при этом среднее время функционирования ортопедиче- ских конструкций до наступления осложнений составило 8,5 года.

В группах, в которых, с целью создания опор под несьемные ортопедические конструкции использовались сочетание различных видов имплантатов (II - VI групп), средний процент осложнений составил 8,8 \% от общего количества пациентов в группах. При этом средний срок службы несъемных ортопедических конструкций, нуждающихся в снятии, составило 8 лет.

Таким образом, на основании обследований можно сделать следующее заключение:

Мультимодальный подход в дентальной имплантологии, является эффективным методом создания опор под несъемные ортопедические конструкции, и не чем не уступает методике в которой используются исключительно двухэтапные винтовые цилиндрические имплантаты.

Процент осложнений в контрольной группе составил 8,3 \%, а в исследуемых группах 8,8 \%, при этом средний срок функционирования несъемных ортопедических конструкций, которые потеряли свою функциональную ценность в контрольной группе составило 8,5 года, а в исследуемых -8 лет.

Bыbоды. Сочетание различных винтов дентальных имплантатов, для создания опор под несъемные ортопедические конструкции является эффективной методикой по восстановлению функции жевания. Процент осложнения у лиц, у которых двухэтапные винтовые имплантаты служили опорой несъемной ортопедической конструкции, составил 8,3 \%, а у лиц которым был применен мультимодальный подход для создания опор под несъемную конструкцию $-8,5 \%$. 


\section{Список литературы}

1. Сенников О. Н. Клиническая оценка долговременного функционирования различных имплантатов, используемых для восстановления дефектов зубных рядов / О. Н. Сенников, В. А. Лабунец, А. М. Сенникова // Дентальные технологии. -2005 . - № 7. - С. 62.

2. Суров О. Н. Субкортикальная имплантация / О. Н. Суров // Новое в стоматологии. - 1993. - № 3. С. 24-25.

3. Научные основы разработки и применения современных дентальных имплантатов / В. Лясников, К. Бутовский, А. Лепилин [и др.] // Клиническая имплантология и стоматология. - 1998. - № 2. - С. 30-34.

4. Семенов Е. И. Отдаленные результаты использования различных видов дентальных имплантатов при дефектах зубного ряда различной протяженности у больных генерализованным пародонтитом / Е. И. Семенов, В. А. Лабунец, О. Н. Сенников // Вісник стоматології. - 2012. - № 6 (спецвипуск). - С. 75-77.

5. Шелест Є. П. Пластинкові імплантати. «За» і «проти» 20-річний досвід застосування / Є. П. Шелест // Імплантологія. Пародонтологія. Остеологія. - 2007. - № 1. C. $28-29$.

6. Джанкарло Кортезе Повернення до підокісних імплантацій них технік з використанням найновіших досягнень технології / Джанкарло Кортезе. // Імплантологія. Пародонтологія. Остеологія. - 2007. - № 4. - С. 25-40.

7. Mc Alister M. L. Applikation of stereolihography to subperiosteal implant manufacture / Mc Alister M. L. // Oral implantol. - 1998. - № 24. - P. 289-292.

8. Вовк В. С. Досвід застосування імплантатів фігурної форми в дистальних відділах нижньої щелепи / В. Є Вовк, С. Б. Нурмаганов, А. Жумабеков // Імплантологія. Пародонтологія. Остеологія. - 2009. - № 2. - С. 46-52.

9. Клинический опыт использования резорбируемых мембран для направленной регенерации тканей пародонта / В. А. Вигдерович, Г. В. Дробот, М. А. Талалай [и др.]. // Проблемы стоматологии и нейростоматологии. - 1999. - № 2. - C. 50.

10. Жусев А. И. Использование пластиночных имплантатов и перспективы развития метода / А. И. Жусев // Проблемы стоматологии и нейростоматологии. - 1999. - № 2. - C. 51-52.

11. Лабунец В. А. Двенадцатилетний опыт использования различных видов имплантатов, служащих опорой для несъемных ортопедических конструкций, при их раннем на- гружении / В. А. Лабунец, Е. И. Семенов, О. Н. Сенников // Вісник стоматології. - 2012. - № 1. - С. 58-62.

\section{REFERENS}

1. Sennikov O. N., Labunets V. A., Sennikova A. M. Clinical evaluation of the long-term functioning of various implants used to repair dental defects Dental'nye tekhnologii. 2005; 7:62

2. Surov O. N. Subcortical implantation. Novoe $v$ stomatologii. 1993;3:24-25.

3. Lyasnikov V., Butovskiy K., Lepilin A. [i dr.] Scientific bases of development and application of modern dental implants. Klinicheskaya implantologiya $i$ stomatologiya. 1998;2:30-34.

4. Semenov E. I., Labunets V. A., Sennikov O. N. Longterm results of using different types of dental implants for dental defects of various lengths in patients with generalized periodontitis. Visnyk stomatologii'. 2012;6:75-77.

5. Shelest Je. P. Plate implants. "For" and "against" 20year experience of application. Implantologija. Parodontologija. Osteologija. - 2007. - № 1. - C. 28-29.

6. Dzhankarlo Korteze. Return to the latest implantations and techniques using the latest technology advances. Implantologija. Parodontologija. Osteologija. 2007;4:25-40.

7. Mc Alister M. L. Applikation of stereolihography to subperiosteal implant manufacture. Oral implantol. 1998;24:289-292.

8. Vovk V. Je. Nurmaganov S. B., Zhumabekov A. Experience in using shaped implants in the distal parts of the lower jaw. Implantologija. Parodontologija. Osteologija. 2009;2:4652 .

9. Vygderovych V. A., Drobot G. V., Talalaj M. A. [y dr.]. Clinical experience with the use of resorbable membranes for guided tissue regeneration of periodontal. Problembl stomatologyy y nejrostomatologyy. 1999;2:50.

10. Zhusev A. Y. The use of plate implants and prospects for the development of the method. Problemy stomatologii $i$ nejrostomatologii. 1999;2:51-52.

11. Labunec V. A. Semenov E. I., Sennikov O. N. Twelve years of experience in using various types of implants that support fixed orthopedic structures when they are loaded early. Visnyk stomatologii'. 2012;1:58-62.

Поступила 08.04.20 